\author{
PLATO AND THE \\ MYTHIC TRADITION IN \\ POLITICAL THOUGHT
}





\section{PLATO AND THE MYTHIC TRADITION IN POLITICAL THOUGHT}

TAE-YEOUN KEUM

THE BELKNAP PRESS OF HARVARD UNIVERSITY PRESS

Cambridge, Massachusetts London, England 
Copyright (c) 2020 by the President and Fellows of Harvard College All rights reserved

Printed in the United States of America

\author{
First printing \\ Jacket design: Annamarie Why \\ Jacket photo: RichSTOCK / Alamy Stock Photo \\ 9780674250161 (EPUB) \\ 9780674250178 (MOBI) \\ 9780674250185 (PDF)
}

THE LIBRARY OF CONGRESS HAS CATALOGED THE PRINTED EDITION AS FOLLOWS:

Names: Keum, Tae-Yeoun, 1986- author.

Title: Plato and the mythic tradition in political thought / Tae-Yeoun Keum. Description: Cambridge, Massachusetts : The Belknap Press of Harvard University Press, 2020. | Includes bibliographical references and index. Identifiers: LCCN 2020014658 | ISBN 9780674984646 (cloth)

Subjects: LCSH: Plato-Influence. | Rationalism-Political aspects—History. | Mythology_Political aspects-History. | Political science-Philosophy.

Classification: LCC B395.K43 2020 | DDC 184-dc23

LC record available at https://lccn.loc.gov/2020014658 
For Dong-Yeoun Lee and In-Ho Keum 
